
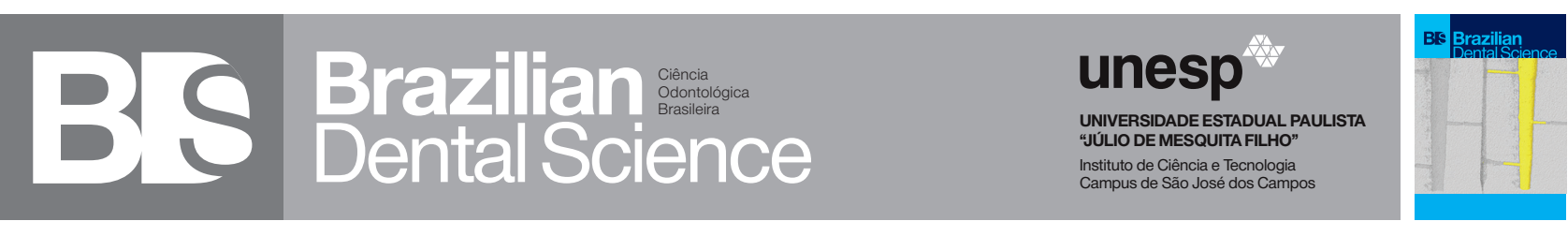

\title{
Influence of the calcium hydroxide paste vehicle on penetration into lateral canals
}

\author{
Influência do veículo da pasta de hidróxido de cálcio na penetração em canais laterais
}

Amanda Sousa VIDAL ${ }^{1}$, Daniele Aparecida LEÃO ${ }^{1}$, Fernanda Mota GUIMARÃES ${ }^{1}$, Mariana de Oliveira GONÇALVES ${ }^{1}$, Raíssa Freitas PINHEIRO $^{1}$, Tereza Cristina Rodrigues da CUNHA ${ }^{1}$, Marco Antonio Hungaro DUARTE ${ }^{2}$, Jussaro Alves DUQUE ${ }^{2}$

1 - National Institute of Higher Education and Post-graduation Priest Gervásio - Pouso Alegre - MG - Brazil.

2 - Department of Restorative Dentistry, Dental Materials and Endodontics - Bauru Dental School - University of São Paulo - Bauru - SP - Brazil.

\begin{abstract}
Objective: The aim of this study was to use Micro computed tomography (micro-CT) to evaluate the influence of the type of vehicle associated with calcium hydroxide on its ability to penetrate simulated lateral canals. Material and Methods: 30 acrylic blocks with simulated lateral canals comprising apical, middle and cervical thirds were used in the in vitro study. The blocks were divided into 3 groups $(n=10)$ according to the type of vehicle used (chlorhexidine, distilled water and propylene glycol) in the calcium hydroxide slurry, which was inserted in the respective group of simulated canals with a $\mathrm{K \#} 30$ file and then agitated with an ultrasonic tip. The blocks were scanned by micro-computed tomography (micro-CT) before and after insertion of the medication. The images obtained were reconstructed and analyzed to obtain the initial volume of lateral canals and the volume of medication that penetrated into them. Results: In the intragroup analysis, both distilled water and chlorhexidine $2 \%$ were observed to present statistical difference in all thirds of the canal. Propylene glycol showed no intragroup difference. In the inter-group analysis, the propylene glycol paste presented higher values of penetration into the simulated lateral canals than the other groups $(p<0.05)$. Conclusion: Propylene glycol used as vehicle of the calcium hydroxide paste provided better penetration results in simulated lateral canals.
\end{abstract}

\section{KEYWORDS}

Endodontics; Calcium hydroxide; Propylene glycol.

\section{RESUMO}

Objetivo: O objetivo desse estudo foi avaliar por meio da microtomografia computadorizada a influência do tipo de veículo associado ao hidróxido de cálcio na capacidade de penetrar em canais laterais simulados. Material e Métodos: No estudo foram utilizados 30 blocos de acrílico com canais laterais simulados nos terços apical, médio e cervical. Os blocos foram divididos em 3 grupos $(n=10)$ de acordo com o tipo de veículo utilizado (clorexidina, água destilada e propilenoglicol) na pasta de hidróxido de cálcio, foram inseridos com auxílio de uma lima tipo $\mathrm{k} 30 \mathrm{e}$ em seguida agitadas com ultrassom. Os blocos foram escaneados em microtomografia computadorizada antes e após a inserção da medicação. As imagens obtidas foram reconstruídas e analisadas obtendo o volume inicial dos canais laterais e o volume de medicação que penetrou nos mesmos. Resultados: $\mathrm{Na}$ análise estatística intragrupo observou-se que tanto a água destilada quanto a clorexidina $2 \%$ apresentaram diferença estatística em todos os terços do canal. O propilenoglicol não apresentou diferença intragrupo. Já na análise entre os grupos, a pasta com propilenoglicol apresentou maior penetração nos canais laterais simulados $(\mathrm{p}<0,05)$. Conclusão: O propilenoglicol utilizado como veículo da pasta de hidróxido de cálcio permitiu melhores resultados de penetração em canais laterais simulados.

\section{PALAVRAS-CHAVE}

Endodontia; Hidróxido de cálcio; Propilenoglicol. 


\section{INTRODUCTION}

Thenter. he purpose of endodontic therapy is to remove microorganisms, and prevent re-infection within root canal systems [1]. This is why the need for good chemicalmechanical preparation has been emphasized, however, previous studies have reported that instrumentation and irrigation only are insufficient for effectively reducing the microbial load in endodontic infection [2]. In view of the foregoing, the use of intracanal medications such as calcium hydroxide is necessary to eliminate the microorganisms that remain after chemical mechanical preparation [3].

Calcium hydroxide is the preferred medication in endodontic treatment [1-2]. This is due to its antimicrobial action, alkalizing effect, induction of mineralization and control of inflammatory root resorption, in addition to acting as a physical barrier, preventing the penetration of new microorganisms [3-4]. Its effectiveness is largely related to its capacity for penetrating into the dentinal tubules, and into anatomically complex areas such as the lateral canals. Therefore, calcium hydroxide is combined with different vehicles to enable it to penetrate into root canal systems and act in an effective manner [2].

The literature has proposed the use of different types of vehicles, however, the most frequently used has been distilled water and propylene glycol, which is a viscous vehicle. In addition to these, a new proposal has been the association of two medications, in which $2 \%$ chlorhexidine gel has been used in association with calcium hydroxide [5].

Micro-computed tomography (microCT) has been used in different areas of endodontics as an analytical resource, due to its capacity for obtaining details of the structures in question and reproducing them in three dimensions. Furthermore, because it does not destroy the sample, it is possible to make comparisons at different stages [6]. Nevertheless, up to now there are no studies using microCT as a way to analyze the influence the vehicle of calcium hydroxide paste has on its penetration into lateral canals [7].
Taking into consideration the importance of calcium hydroxide penetrating into the entire root canals system, and to enable this to be more efficient, the aim of this study was to use microCT to evaluate the influence of the type of vehicle associated with calcium hydroxide on its capacity for penetrating into simulated lateral canals. The null hypothesis tested was that the vehicle would not interfere in the penetration of the paste into lateral canals.

\section{MATERIAL \& METHODS}

\section{Preparation of canals in acrylic blocks}

Thirty (30) acrylic blocks were used, with simulated lateral canals comprising cervical, middle and apical thirds. The lateral canals had a diameter compatible with that of a type K 08 file. Initially the real working length of the canal was established by introducing a type K No.10 file until its tip was visualized at the canal outlet. After this, $1 \mathrm{~mm}$ was subtracted thus obtaining the real working length. With the purpose of simulating a condition close to that found clinically, each block was molded with condensation silicone (Clonage; DFL, Rio de Janeiro, RJ, Brazil) and inserted into a metal muffle with the intention of obtaining a closed system.

The canals were instrumented using R25.08 instruments (Reciproc, VDW, Germany), and the process was divided into 3 stages. In the first stage, preparation of the cervical third was performed; then the middle third, and lastly the apical third. Between each stage, the canal was irrigated with $3 \mathrm{~mL}$ of distilled water, using a syringe and $30 \mathrm{G}$ caliber needle (NaviTip, Ultradent, Brazil). Afterwards a hybridization of techniques was used to instrument the working length with a 40.04 file of the Mtwo rotary system (VDW, Germany). On conclusion, final irrigation was performed with $5 \mathrm{ml}$ distilled water and ultrasonic irrigation with the Irrisonic appliance (Helse Dental Technology; São Paulo, Brazil) coupled to a Varios 350 (NSK Ind. e Com., Tokyo, Japan) ultrasound device at power 2. On conclusion of canal preparations, the specimens were dried with absorbent paper cones. Before inserting the medication, a K 08 file was inserted into the lateral canals to confirm that they were unobstructed. 


\section{Insertion of intracanal medication into the canals in acrylic blocks}

The blocks were randomly divided into 3 groups $(\mathrm{N}=10)$, according to the type of intracanal medication used: G1 - calcium hydroxide $+2 \%$ chlorhexidine; G2 - calcium hydroxide + distilled water; G3 - calcium hydroxide + propylene glycol. For all the groups the same quantity of intracanal medication was used, which was established by pilot tests which 0.065 grams of paste were made available for each specimen. The proportion was 1 gram of calcium hydroxide powder to $1 \mathrm{~mL}$ of vehicle (chlorhexidine, distilled water and propylene glycol). For inserting the medication, a type $\mathrm{K}$ No.30 file was used to place the calcium hydroxide into the main canal, and afterwards this was agitated for 20 seconds using the Irrisonic insert (Helse Dental Technology; São Paulo, Brazil), positioned $2 \mathrm{~mm}$ short of the working length, and coupled to an ultrasound device at power 2 . The same procedure was repeated another two times, and in the intervals, the main canal was again filled with the medication, with the aid of a type K No.30 file.

\section{Evaluation of Specimens}

The specimens were scanned before and after placement of the intracanal medication, by means of micro-computed tomography (SkyScan 1174v2, SkyScan, Kontich, Belgium). The first scan was performed to determine the volume of the lateral canals, so that this would serve as a basis for calculating the percentage of volume filled after placement of the paste. (Figure 1).

The following parameters were adopted for the scans: power of the X-ray source with $50 \mathrm{kV}$ and $800 \mu \mathrm{A}$; aluminum filter of $0.5 \mathrm{~mm}$, with pixel size of $19.70 \mu \mathrm{m}$, with a rotation step of 1.0 degrees and 180 degrees rotation of the X-ray tube/detector, generating twodimensional images with1304 x 1024 pixels.

The images obtained by scanning were reconstructed by means of NRecon software (NReconv 1.6.4.8, SkyScan, Aartselaar, Belgium). The CTAN software (CTAN v1.11.10.0, SkyScan) was used for measuring the initial volume of the lateral canals, and after insertion of the intracanal medication. Analysis was limited to the area of interest (ROI) for each sample, which were the lateral canals in the cervical, middle and apical thirds.

\section{Statistical Analysis}

The data obtained were submitted to the Shapiro-Wilk test that showed absence of normality. After this, the non-parametric KruskalWallis test was applied for inter-group analysis and the Dunn test for intra-group analysis. The level of significance adopted was 5\%.

Calcium hydroxide $+2 \%$ Chlorhexidine

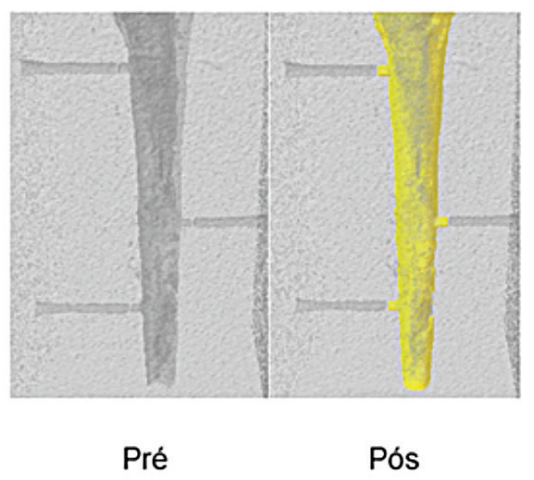

Calcium hydroxide + Distilled Water

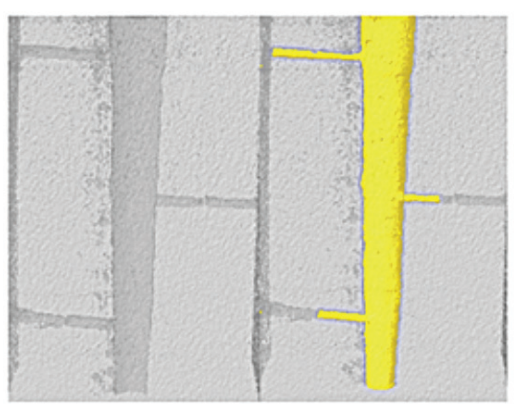

Pré

Pós
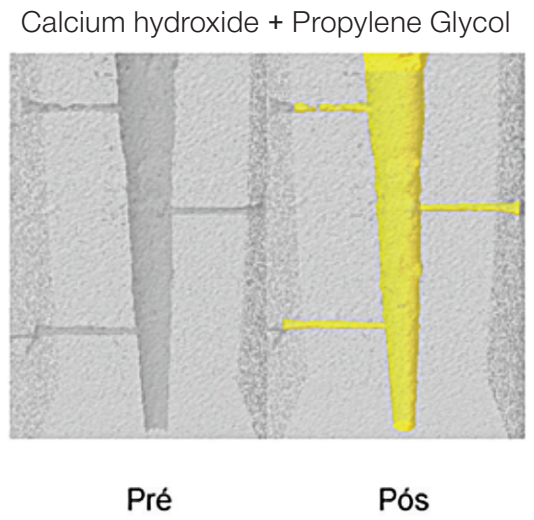

Figure 1 - micro-computed tomographic images representing situation before and after insertion of intracanal medication, using the different vehicles - $2 \%$ Chlorhexidine, Distilled Water and Propylene Glycol. 


\section{RESULTS}

In the statistical analysis, the initial volume of the canals was shown to present no significant difference among the groups, showing an adequate pairing among them ( $\mathrm{p}$ $>0.05$ ).

In Table, the intra-group analyses may be observed, in which the 2\% Chlorhexidine and distilled water Group presented statistical difference relative to initial canal volume and penetration of intracanal medication, at all levels $(\mathrm{P}<0.05)$. Whereas, the propylene glycol showed no statistical difference in any of the thirds ( $p>0.05)$.

In the inter-group analysis, irrespective of the third analyzed, the group in which propylene glycol was used as vehicle was capable of better penetration into the lateral canal, with significant difference in comparison with the group that used Chlorhexidine as vehicle $(\mathrm{p}<0.05)$. The propylene glycol and distilled water group showed no significant differences between them $(\mathrm{p}>0.05)$.

Table 1 - Median, minimum and maximum values of lateral canal volume ( $\mathrm{mm} 3)$, and intracanal medication that penetrated into them; and the percentage values of lateral canal filling with calcium hydroxide paste, used with different vehicles.

\begin{tabular}{cccc} 
& CHLORHEXIDINE & $\begin{array}{c}\text { DISTILLED } \\
\text { WATER }\end{array}$ & $\begin{array}{c}\text { PROPYLENE } \\
\text { GLYCOL }\end{array}$ \\
\hline $\begin{array}{c}\text { Lateral Canal } \\
\text { apical third }\end{array}$ & $\begin{array}{c}0.455^{\mathrm{a}} \\
(0.376-0.605)\end{array}$ & $\begin{array}{c}0.401^{\mathrm{a}} \\
(0.339-0.572)\end{array}$ & $\begin{array}{c}0.376^{\mathrm{a}} \\
(0.323-0.605)\end{array}$ \\
Apical filling & $0.006^{\mathrm{b}}$ & $0.154^{\mathrm{b}}$ & $0.362^{\mathrm{a}}$ \\
& $(0.001-0.098)$ & $(0.001-0.572)$ & $(0.060-0.534)$ \\
Lateral Canal & $0.366^{\mathrm{a}}$ & $0.429^{\mathrm{a}}$ & $0.383^{\mathrm{a}}$ \\
middle third & $(0.339-0.556)$ & $(0.317-0.789)$ & $(0.328-0.789)$ \\
Middle filling & $0.058^{\mathrm{b}}$ & $0.176^{\mathrm{b}}$ & $0.333^{\mathrm{a}}$ \\
Lateral Canal & $(0.015-0.070)$ & $(0.037-0.404)$ & $(0.080-0.363)$ \\
cervical third & $0.414^{\mathrm{a}}$ & $0.415^{\mathrm{a}}$ & $0.384^{\mathrm{a}}$ \\
& $(0.351-0.600)$ & $(0.349-0.525)$ & $(0.316-0.522)$ \\
Cervical filling & $0.076^{\mathrm{b}}$ & $0.143^{\mathrm{b}}$ & $0.306^{\mathrm{a}}$ \\
& $(0.027-0.141)$ & $(0.011-0.522)$ & $(0.117-0.522)$ \\
Apical filling \% & $1.32^{\mathrm{A}}$ & $37.84^{\mathrm{AB}}$ & $100 /{ }^{\mathrm{B}}$ \\
& $(0.22-16.49)$ & $(0.19-100)$ & $(16.85-100)$ \\
Middle filling \% & $14.44^{\mathrm{A}}$ & $27.49^{\mathrm{AB}}$ & $94.311^{\mathrm{B}}$ \\
& $(4.05-17.56)$ & $(8.13-100)$ & $(17.49-100)$ \\
Cervical filling \% & $17.97^{\mathrm{A}}$ & $33.33^{\mathrm{AB}}$ & $83.01 \mathrm{~B}^{\mathrm{B}}$ \\
& $(7.69-36.53)$ & $(2.75-100)$ & $(31.97-100)$ \\
\hline
\end{tabular}

Different capital letters indicate statistically significant differences within the same group $(p<0.05)$

Different lower case letters indicate statistical difference between the groups $(p<0.05)$

\section{DISCUSSION}

It is of fundamental importance for the calcium hydroxide paste used as intracanal medication to enter into the dentinal tubules and anatomically complex regions, so that adequate control of the microorganism confined within them occurs $[1,8]$. The vehicles used with calcium hydroxide may have an influence on the behavior of the paste and on its penetration [3-4]. According to a study that evaluated the influence of 3 vehicles used in calcium hydroxide paste (chlorhexidine, distilled water and propylene glycol) on the capacity of its penetration into simulated lateral canals by means of micro-computed tomography.

Micro-computed tomography has been a widely used tool because of its capacity to evaluate samples at different stages because it was unnecessary to destroy the sample in question. Different studies have pointed out that it is a reliable methodology that presents more objective results because it is a three dimensional (3D) analysis [9-11].

In all the groups the Irrisonic ultrasound insert was used to perform agitation of the intracanal medication. This was performed based on previous studies [12-13], in which the authors observed better penetration of the calcium hydroxide paste when it was agitated with ultrasound.

In the present study, the $2 \%$ Chlorhexidine Group could be observed to present statistical difference in all the root canal thirds, and this was the association that provided the lowest capacity of penetration into the lateral canals compared with propylene glycol. Distilled water showed no statistical difference compared with the other groups, in spite of presenting a much lower penetration percentage than that of propylene glycol. There were no studies in the literature with the same type of analysis which could be compared with the results of the present study, however, studies in which diffusion of the medication was analyzed, showed contradictory results, in which chlorhexidine and distilled water showed better diffusion into the dentinal tubules than propylene glycol $[4,14]$. However, in another study [15], propylene glycol presented the best results for diffusion of the medication into the 
dentinal tubules. The controversies among the studies may be related to the proportions used in the pastes, or as a result of differences in the methodology.

Nevertheless, another study [3] corroborated the results of our study, in which penetration of the calcium hydroxide pastes with distilled water or propylene glycol presented a similar level of penetration.

Important to infer, is that in the abovementioned studies, agitation of the intracanal medication with ultrasound was not performed. This fact may lead to different behaviors of the vehicles used towards the mechanical effect produced by ultrasound, either by improving penetration of the intracanal medication, or not. As observed in other studies [12-13] that agitated the paste, there was greater diffusibility of the calcium hydroxide paste into the dentinal tubules when using propylene glycol as vehicle in comparison with the paste manipulated with distilled water. Furthermore, it is important to point out that propylene glycol is a viscous vehicle that has low surface tension, which favors its penetration into anatomically complex areas [12,13], as was observed in the present study. Relative to the other vehicles used, penetration into the lateral canals may have been harmed due to the consistency of the chlorhexidine gel, and by the hydrophilic action produced by calcium hydroxide when manipulated with distilled water, leading to these pastes having a lower level of diffusibility. In spite of agitating the paste with ultrasound, these factors could have influenced the lower results obtained when compared with propylene glycol as vehicle.

In the intra-group analyses, it could be observed that in the 2\% Chlorhexidine and distilled water Group, there was statistical difference between the initial canal volume (empty) and penetration of intracanal medication into the canal, at all levels analyzed. These results demonstrated that there was unsatisfactory penetration of the medication into the lateral canals for these groups. In the Propylene Glycol Group the results presented no statistically significant difference in any of the root thirds analyzed, revealing adequate penetration of the medication at all levels.

\section{CONCLUSION}

Based on the results of the present study, it was possible to conclude that propylene glycol used as vehicle in calcium hydroxide paste, and the slurry agitated with ultrasound, presented the best results of intracanal medication penetration into simulated canals at all levels.

\section{REFERENCES}

1. Turk BT, Shen BH, Ozturk T. In vitro antimicrobial activity of calcium hydroxide mixed with different vehicles against Enterococcus faecalis and Candida albicans. Oral Surg Oral Med Oral Pathol Oral Radiol Endod. 2009 Aug;108(2):297-301.

2. Ganesh MR, Chaurasia VR, Masamatti VK, Mujeeb A, Jhamb A, Agarwal JH. In vitro evaluation of antibacterial efficacy of calcium hydroxide in different vehicles. J Int Soc Prev Community Dent. 2014 Jan;4(1):56-60.

3. Deniz Sungur D, Aksel H, Purali N. Effect of a Low Surface Tension Vehicle on the Dentinal Tubule Penetration of Calcium Hydroxide and Triple Antibiotic Paste. JEndod. 2017 Mar;43(3):452-5

4. MoriGG, Ferreira FC, BatistaFR, Godoy AM, Nunes DC. Evaluation of the diffusion capacity of calcium hydroxide pastes through the dentinal tubules. Braz Oral Res. 2009 Apr-Jun;23(2):113-8

5. Dutta B, Dhull KS, Das D, Samir PV, Verma RK, Singh N. Evaluation of Antimicrobial Efficacy of various Intracanal Medicaments in Primary Teeth: An in vivo Study. Int J Clin Pediatr Dent. 2017 Jul-Sep;10(3):267-71.

6. Ma JZ, Shen Y,Al-Ashaw AJ, Khaleel HY, Yang Y, Wang ZJ, Peng B, Haapasalo M. Micro-computed tomography evaluation of the removal of calcium hydroxide medicament from C-shaped root canals of mandibular second molars. IntEndod J.2015 Apr;48(4):333-41.

7. Alencar AHG, Figueiredo JAP,Estrela C. Microtomografia computadorizada na avaliação do preparo do canal radicular: análise crítica. ROBRAC. 2008;17(44):159-65.

8. Ricucci D, Loghin S, Siqueira JF Jr. Exuberant Biofilm infection in a lateral canal as the cause of short-term endodontic treatment failure: report of a case. $J$ Endod. 2013 May;39(5):712-8.

9. Bernardes RA, Duarte MA, Vivan RR, Alcalde MP, Vasconcelos BC, Bramante $\mathrm{CM}$. Comparison of three retreatment techniques with ultrasonic activation in flattened canals using micro-computed tomography and scanning electron microscopy. Int Endod J. 2016 Sep;49(9):890-7.

10. Duque JA, Vivan RR, Cavenago BC, Amoroso-Silva PA, Bernardes RA, Vasconcelos BC, Duarte MA. Influence of NiTialloy on the root canal shaping capabilities of the ProTaper Universal and ProTaper Gold rotary instrument systems. J Appl Oral Sci. 2017 Jan-Feb;25(1):27-33.

11. Duque JA, Fernandes SL, Bubola JP,Duarte MAH, Camilleri J, Marciano MA The effect of mixing method on tricalcium silicate-based cement. Int Endod J 2018 Jan;51(1):69-78.

12. Duarte MA, Balan NV,Zeferino MA, Vivan RR, Morais CA, Tanomaru-Filho M, et al. Effect of ultrasonic activation on $\mathrm{pH}$ and calcium released by calcium hydroxide pastes in simulated external root resorption. J Endod. 2012 Jun;38(6):834-7. 
13. Arias MP,Maliza AG, Midena RZ Graeff MS, Duarte MA, Andrade FB. Effect of ultrasonic streaming on intra-dentinal disinfection and penetration of calcium hydroxide paste in endodontic treatment. J Appl Oral Sci. 2016 NovDec;24(6):575-81.

14. Pacios MG, de la Casa ML, de Bulacio MI, López ME. Influence of different vehicles on the pH of calcium hydroxide pastes. J Oral Sci. 2004 Jun;46(2):107-11.
15. Shetty S, Manjunath MK, Tejaswi S. An In-vitro Evaluation of the pHChange Through Root Dentin Using Different Calcium Hydroxide Preparations as an Intracanal Medicament. J Clin Diagn Res. 20140ct;8(10):ZC13-6.

\section{Jussaro Alves Duque}

(Corresponding address)

Alameda Octávio Pinheiro Brisola no. 9-75

17012-901, Bauru, São Paulo, Brasil

Date submitted: 2018 Mar 22

E-mail: jussaroduque@usp.br 